\title{
Chromosome evolution in the erythrinid fish, Erythrinus erythrinus (Teleostei: Characiformes)
}

\author{
LAC Bertollo $^{1}$, C Oliveira ${ }^{2}$, WF Molina ${ }^{3}$, VP Margarido ${ }^{4}$, MS Fontes ${ }^{1}$, MC Pastori ${ }^{5}$, J das N Falcão ${ }^{6}$ and \\ AS Fenocchio ${ }^{5}$ \\ ${ }^{1}$ Departamento de Genética e Evolução, Universidade Federal de São Carlos, São Carlos, SP, Brazil; ${ }^{2}$ Universidade Estadual Paulista, \\ Campus de Botucatu, SP, Brazil; 'Departamento de Ciências Biológicas, Universidade Federal do Rio Grande do Norte, Natal, RN, Brazil; \\ ${ }^{4}$ Universidade Estadual do Oeste do Paraná, Campus de Cascavel, PR, Brazil; ${ }^{5}$ Departamento de Genética, Universidad Nacional de \\ Misiones, Posadas, Argentina; ${ }^{\circ}$ Departamento de Biologia, Universidade Federal do Amazonas, Manaus, AM, Brazil
}

\begin{abstract}
The genus Erythrinus belongs to the family Erythrinidae, a neotropical fish group. This genus contains only two described species, Erythrinus erythrinus being the most widely distributed in South America. Six samples of this species from five distinct Brazilian localities and one from Argentina were studied cytogenetically. Four groups were identified on the basis of their chromosomal features. Group A comprises three samples, all with $2 n=54$ chromosomes, a very similar karyotypic structure, and the absence of chromosome differentiation between males and females. One sample bears up to four supernumerary microchromosomes, which look like 'double minute chromosomes' in appearance. Groups B-D comprise the three remaining samples, all sharing an $X_{1} X_{1} X_{2} X_{2} / X_{1} X_{2} Y$ sex chromosome
\end{abstract}

system. Group B shows $2 n=54 / 53$ chromosomes in females and males, respectively, and also shows up to three supernumerary microchromosomes. Groups C and D show $2 n=52 / 51$ chromosomes in females and males, respectively, but differ in the number of metacentric, subtelocentric, and acrocentric chromosomes. In these three groups (B-D), the $Y$ is a metacentric chromosome clearly identified as the largest in the complement. The present results offer clear evidence that local samples of $E$. erythrinus retain exclusive and fixed chromosomal features, indicating that this species may represent a species complex.

Heredity (2004) 93, 228-233, advance online publication, 30 June 2004; doi:10.1038/sj.hdy.6800511

Keywords: Erythrinus fish; chromosomal diversity; sex chromosomes

\section{Introduction}

Fish are the most primitive vertebrate group, may be found in several types of environments, and show wide genetic variability both at the chromosomal and molecular levels, which makes them an interesting group for evolutionary and cytotaxonomic studies (Kosswig, 1973).

Erythrinidae constitutes a small family of carnivorous fish widely spread in the hydrographic basins of South America, with a preference for lentic environments. This family is divided into three genera Hoplias, Hoplerythrinus, and Erythrinus. Hoplias, with nine species, shows the widest geographic distribution, $H$. malabaricus and $H$. lacerdae being the major representative species of this genus. The genus Hoplerythrinus is composed of three species and the genus Erythrinus of two (Oyakawa, 2003). The species E. erythrinus is broadly distributed in South America and the species E. kessleri is apparently restricted to coastal rivers in the Brazilian State of Bahia (Oyakawa, 2003).

The genus Hoplias is a relatively well analyzed group from the cytogenetic point of view. Studies conducted in $H$. malabaricus showed that several samples diverged

Correspondence: LAC Bertollo, Departamento de Genética e Evolução, Universidade Federal de São Carlos, C.P. 676, São Carlos, SP 13565-905, Brazil.E-mail: bertollo@power.ufscar.br

Received 28 October 2003; accepted 7 April 2004; published online 30 June 2004 with respect to the diploid number, which ranges from $2 n=39$ to $2 n=42$, the chromosome formulae, and the presence or absence of sex chromosome systems (Bertollo et al, 2000). On the other hand, $H$. lacerdae shows a more stable karyotypic structure composed of $2 n=50$ meta-submetacentric chromosomes, both in males and females (Bertollo et al, 1978; Morelli, 1998). Hoplerythrinus unitaeniatus has also shown the occurrence of different karyotypes, with diploid numbers ranging from $2 n=48$ to $2 n=52$ among local populations (Giuliano-Caetano et al, 2001; Bezerra, 2002).

No study describing the karyotype of E. erythrinus has been published until now. Our preliminary data (unpublished) showed some karyotypic diversity among E. erythrinus populations. In this study, we carried out a comparative analysis of the chromosome structure of six local samples of E. erythrinus and provided cytotaxonomic and evolutionary data for this fish group.

\section{Materials and methods}

\section{Samples and chromosome preparation}

Six E. erythrinus samples were obtained from the following regions: (1) Birigui and (2) Penápolis, both located in São Paulo State, Brazil; (3) Resistência, Chaco Province, Argentina; (4) Guaíra, Paraná State, Brazil; (5) Natal, Rio Grande do Norte State, Brazil; and (6) Manaus, Amazonas State, Brazil (Figure 1). A total 
of 61 fish specimens were analyzed. The numbers of specimens for each sample are presented in Table 1.

Chromosomal spreads were obtained through the conventional air-drying method by direct preparation from kidney cells (Bertollo et al, 1978; Foresti et al, 1993). Some specimens were previously stimulated with a yeast solution, used as a mitogenic agent (Lee and Elder, 1980).

\section{Chromosomal analyses}

The diploid number was determined for male and female specimens and at least 50 metaphases were

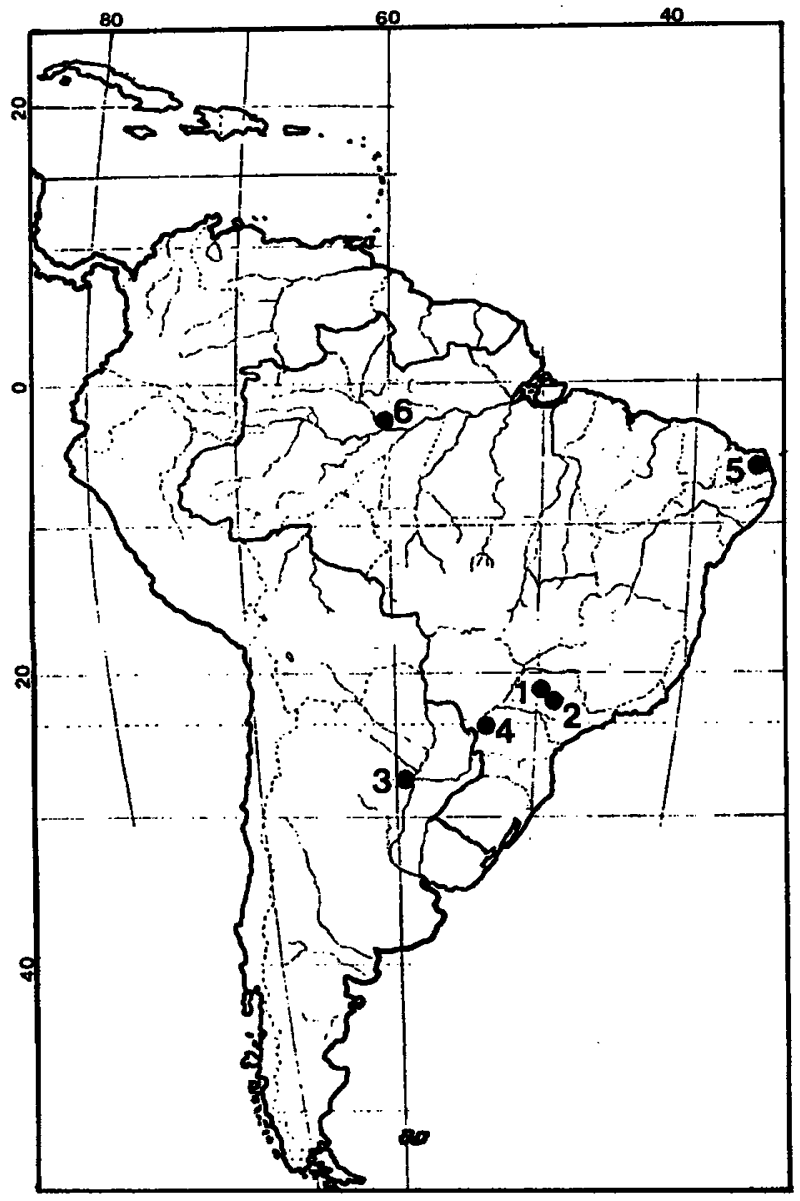

Figure 1 Collection sites of the E. erythrinus samples from Brazil $(1=$ Birigui; $2=$ Penápolis; $4=$ Guaíra; $5=$ Natal and $6=$ Manaus $)$ and Argentina ( $3=$ Resistência). analyzed for each sample (Table 1). The arm ratio (Levan et al, 1964) was used to classify the chromosomes as metacentric $(\mathrm{M})$, submetacentric $(\mathrm{SM})$, subtelocentric (ST), and acrocentric (A), through standardized measurements. The chromosome pairs were organized in a decreasing order of size in the karyotypes.

\section{Results}

A comparative analysis of the E. erythrinus samples shows a general similarity among their karyotypic macrostructure, with few biarmed (meta-, submeta-, and subtelocentric) chromosomes, and a large number of uniarmed (acrocentric) chromosomes (Figures 2-5). Nonetheless, despite this general similarity, significant differentiation in diploid numbers, karyotypic formulae, and the presence of a sex chromosome system is seen, which permits the identification of four distinct groups, named A-D (Figures 2-5; Table 1).

Samples belonging to the group A (samples from Birigui, Penápolis, and Resistência) showed the same diploid number $(2 n=54)$ and karyotypic formulae (6 $\mathrm{M}+2 \mathrm{ST}+46 \mathrm{~A})$, and did not show heteromorphic sex chromosomes (Figure 2; Table 1). On the other hand, samples of the groups B (Guaíra), C (Manaus), and D (Natal) differ from group $\mathrm{A}$ by the presence of a multiple sex chromosome system of the $X_{1} X_{1} X_{2} X_{2} / X_{1} X_{2} Y$ type, besides exclusive karyotypic formulae that characterize each of these groups. Specimens from group B show $2 n=54 / 53$ chromosomes, with $6 \mathrm{M}+2 \mathrm{ST}+46 \mathrm{~A} / 7$ $\mathrm{M}+2 \mathrm{ST}+44 \mathrm{~A}$ in females and males, respectively (Figure 3; Table 1). The groups $\mathrm{C}$ and $\mathrm{D}$ show the same diploid numbers, $2 n=52 / 51$, in females and males, respectively, differing in their karyotypic formulae, that is, $6 \mathrm{M}+2 \mathrm{SM}+6 \mathrm{ST}+38 \mathrm{~A} / 7 \mathrm{M}+2 \mathrm{SM}+6 \mathrm{ST}+36 \mathrm{~A}$ for group $\mathrm{C}$ (Figure 4; Table 1) and $4 \mathrm{M}+2 \mathrm{SM}+2$ $\mathrm{ST}+44 \mathrm{~A} / 5 \mathrm{M}+2 \mathrm{SM}+2 \mathrm{ST}+42 \mathrm{~A}$ for group D (Figure 5; Table 1).

The fishes from Birigui (group A) and Guaíra (group B) displayed supernumerary microchromosomes (Figures $2 \mathrm{a}, 3$ ), which were found in all specimens (two males and two females) from Birigui and five specimens (one male and 4 females) from Guaíra. Up to four supernumeraries were observed in the Birigui sample, and up to three in the Guaíra sample (Table 1). In the Birigui sample, we saw an intraindividual variation in number, indicating that the supernumeraries do not have a regular distribution among the daughter cells during mitosis.

Table 1 Karyotypic data of the four groups (A-D) of E. erythrinus

\begin{tabular}{|c|c|c|c|c|c|c|c|}
\hline Samples & $F$ & $M$ & $\mathrm{~N}$ & $2 n$ & Sex & Chromosome formula & Micro \\
\hline A (Birigui - SP) & 2 & 2 & 50 & 54 & - & $6 \mathrm{M}+2 \mathrm{ST}+46 \mathrm{~A}$ & $0-4$ \\
\hline A (Penápolis - SP) & 5 & 3 & 67 & 54 & - & $6 \mathrm{M}+2 \mathrm{ST}+46 \mathrm{~A}$ & - \\
\hline A (Resistência - AR) & 8 & 9 & 364 & 54 & - & $6 \mathrm{M}+2 \mathrm{ST}+46 \mathrm{~A}$ & - \\
\hline B (Guaíra - PR) & 3 & 5 & 85 & $\begin{array}{l}54(\mathrm{~F}) \\
53(\mathrm{M})\end{array}$ & $\begin{array}{l}X_{1} X_{1} X_{2} X_{2} \\
X_{1} X_{2} Y\end{array}$ & $\begin{array}{l}6 \mathrm{M}+2 \mathrm{ST}+46 \mathrm{~A} \\
7 \mathrm{M}+2 \mathrm{ST}+44 \mathrm{~A}\end{array}$ & $0-3$ \\
\hline C (Manaus - AM) & 6 & 5 & 405 & $\begin{array}{l}52(\mathrm{~F}) \\
51(\mathrm{M})\end{array}$ & $\begin{array}{l}\mathrm{X}_{1} \mathrm{X}_{1} \mathrm{X}_{2} \mathrm{X}_{2} \\
\mathrm{X}_{1} \mathrm{X}_{2} \mathrm{Y}\end{array}$ & $\begin{array}{l}6 \mathrm{M}+2 \mathrm{SM}+6 \mathrm{ST}+38 \mathrm{~A} \\
7 \mathrm{M}+2 \mathrm{SM}+6 \mathrm{ST}+36 \mathrm{~A}\end{array}$ & - \\
\hline D (Natal - RN) & 7 & 6 & 110 & $\begin{array}{l}52(\mathrm{~F}) \\
51(\mathrm{M})\end{array}$ & $\begin{array}{l}X_{1} X_{1} X_{2} X_{2} \\
X_{1} X_{2} Y\end{array}$ & $\begin{array}{l}4 \mathrm{M}+2 \mathrm{SM}+2 \mathrm{ST}+44 \mathrm{~A} \\
5 \mathrm{M}+2 \mathrm{SM}+2 \mathrm{ST}+42 \mathrm{~A}\end{array}$ & - \\
\hline
\end{tabular}

$\mathrm{AR}=$ Argentina; $\mathrm{SP}=$ São Paulo; $\mathrm{PR}=$ Paraná; $\mathrm{RN}=$ Rio Grande do Norte; $\mathrm{AM}=$ Amazonas Brazilian states; $\mathrm{F}=$ females; $\mathrm{M}=\mathrm{males}$; $N=$ number of metaphases analyzed; $2 n=$ diploid number; sex $=$ sex chromosome system; micro = number of microchromosomes observed; $\mathrm{M}=$ metacentric, $\mathrm{SM}=$ submetacentric; $\mathrm{ST}=$ subtelocentric; $\mathrm{A}=$ acrocentric chromosomes. 


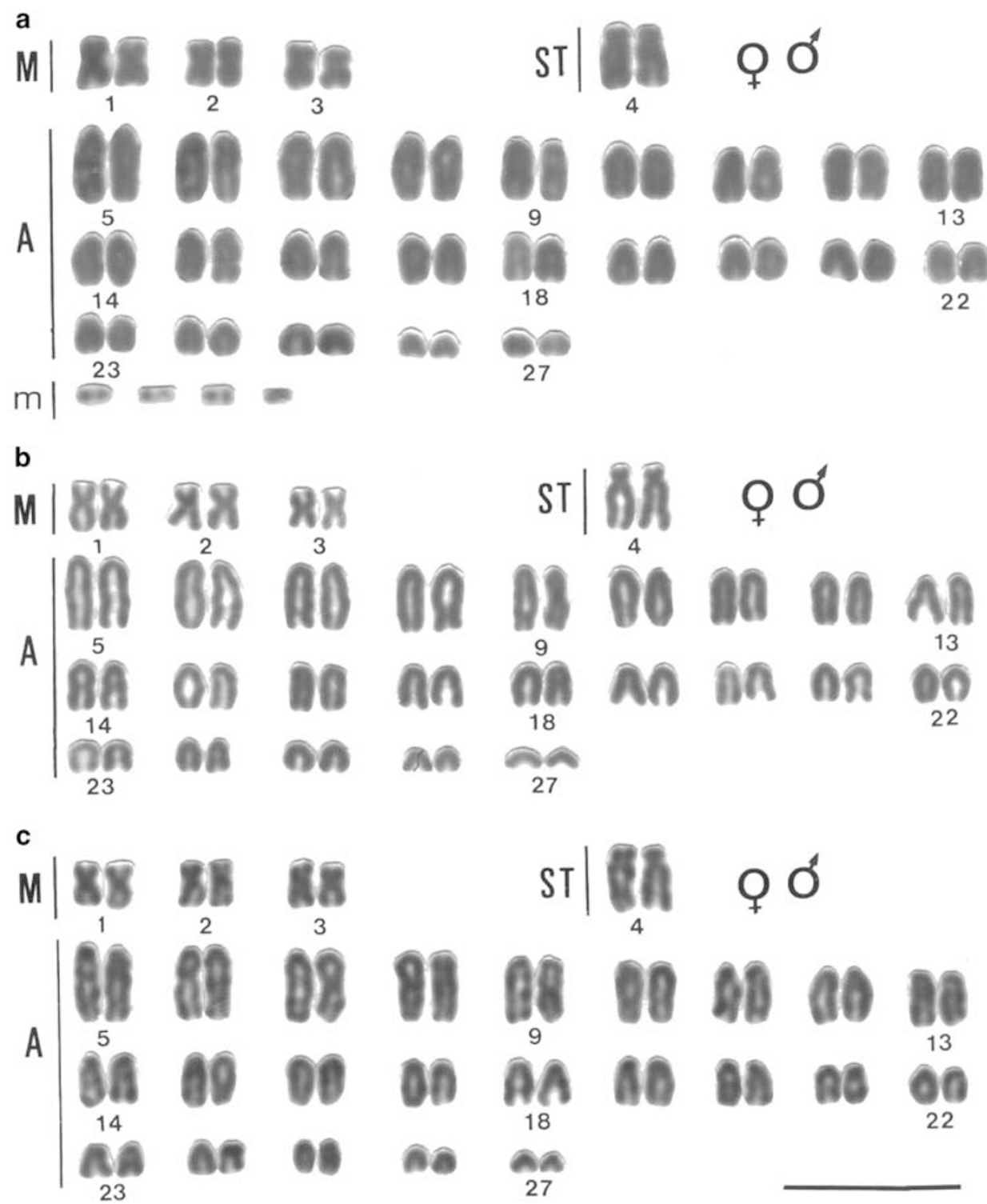

Figure 2 Karyotypes of E. erythrinus from (a) Birigui, (b) Penápolis, and (c) Resistência (group A) showing $2 n=54$ chromosomes without chromosomal differentiation among sexes. The sample from Birigui bears supernumerary microchromosomes $(\mathrm{m})$. Bar $=5 \mu \mathrm{m}$.

\section{Discussion}

The occurrence of a large number of acrocentric chromosomes is a particular feature of the genus Erythrinus among the members of the family Erythrinidae. Indeed, in the other two genera of this family, Hoplias and Hoplerythrinus, acrocentric chromosomes are found only in some samples and in a reduced number (Bertollo et al, 2000; Giuliano-Caetano et al, 2001). Diploid numbers of E. erythrinus $(2 n=52-54)$ are also among the highest in this family. Only a few Hoplerythrinus unitaeniatus samples show $2 n=52$ chromosomes (Giuliano-Caetano et al, 2001; Bezerra, 2002), whereas in the genus Hoplias diploid numbers range from $2 n=50$ in $H$. lacerdae (Bertollo et al, 1978; Morelli, 1998) to $2 n=39-42$ in H. malabaricus (Bertollo et al, 2000).

Ohno (1974) proposed a basic karyotype composed of $2 n=48$ acrocentric chromosomes for teleost fish. Among the Characiformes, which include the family Erythrinidae, the most frequent chromosomal number is $2 n=54$, and may represent the basal diploid number of this order (Oliveira et al, 1988). Taking into account this hypothesis, a diploid number equal to $2 n=54$, with many acrocentric chromosomes and undifferentiated sex chromosomes may correspond to a primitive characteristic in Erythrinidae. Thus, the samples of Erythrinus of group A may have the most primitive karyotype for the family Erythrinidae. According to this hypothesis, the occurrence of smaller diploid numbers, the increase of biarmed chromosomes and the presence of differentiated sex chromosomes represent derived characters among the members of the groups B-D of Erythrinus.

Reduction of the chromosome number in Erythrinus is probably due to fusion/translocation rearrangements, with the participation of the acrocentric chromosomes. Indeed, there is a decrease in the number of acrocentric 


\section{M}

$\mathrm{M} \mid \mathrm{O}$

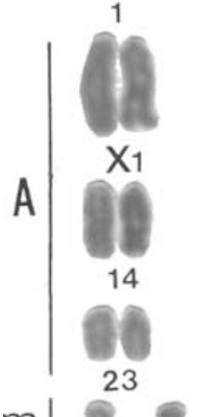

$\mathrm{m} \mid \approx$

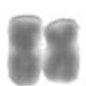

2
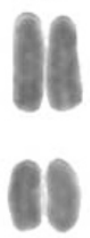

al

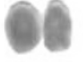

ST
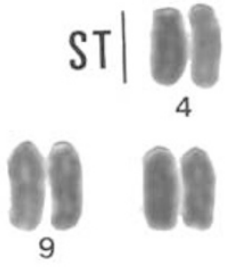

9
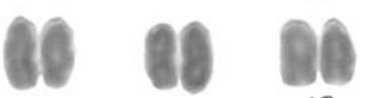

18
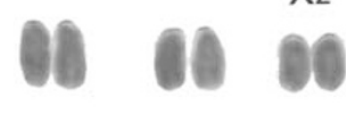

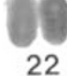

Q

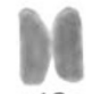

13

22

\section{M}
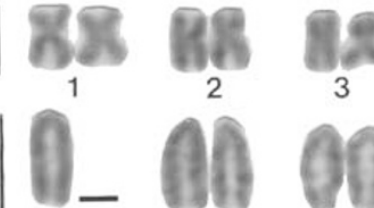

A

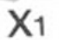

A

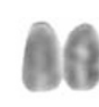

14

23

$\mathrm{m}$$$
\text { 23 }
$$

Figure 3 Karyotypes of E. erythrinus from Guaíra (group B), showing $2 n=54$ chromosomes in females and $2 n=53$ chromosomes in males, with an $X_{1} X_{1} X_{2} X_{2} / X_{1} X_{2} Y$ sex chromosome system. This sample bears supernumerary microchromosomes $(\mathrm{m})$. Bar $=5 \mu \mathrm{m}$.

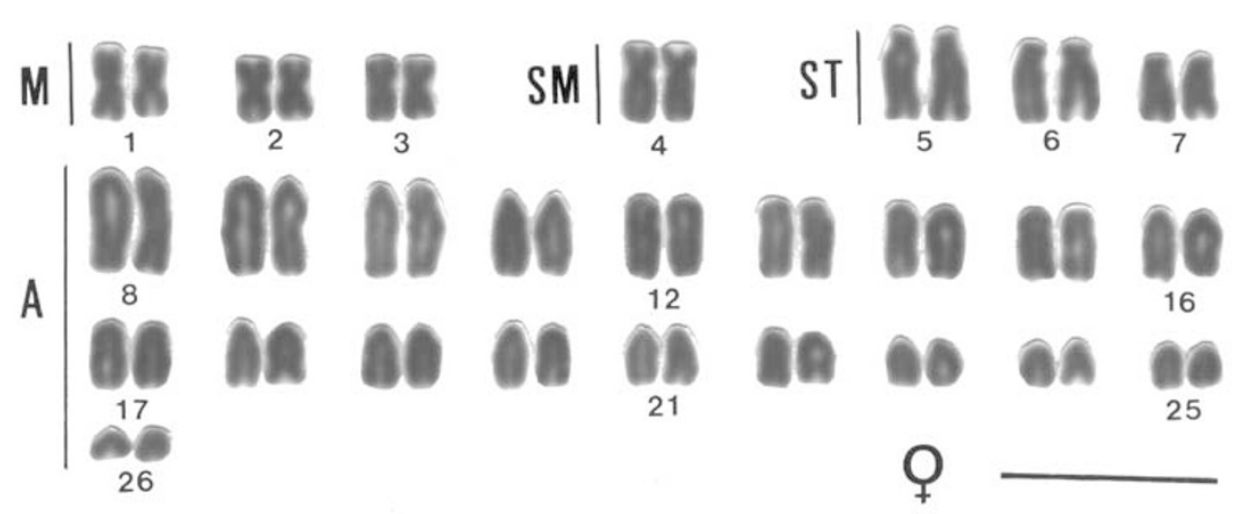

Figure 4 Female karyotype of E. erythrinus from Manaus (group C), showing $2 n=52$ chromosomes. Males present $2 n=51$ chromosomes also due to a multiple sex chromosome system of the $X_{1} X_{1} X_{2} X_{2} / X_{1} X_{2} Y$ type (not showed). Bar $=5 \mu \mathrm{m}$.

chromosomes in the samples with smaller diploid numbers (Table 1). The absence of one of the last acrocentric pairs in the samples of the groups $C$ and D (Figures 4-5), in comparison with the samples of the groups $\mathrm{A}$ and $\mathrm{B}$ (Figures 2 and 3), reinforces this proposition. In parallel, a clear alteration in the number of metacentric and submetacentric chromosomes is also observed, that is, while there are three metacentric pairs of similar size in the samples with $2 n=54 / 54$ or $2 n=54$ / 53 (groups A and B, respectively), there is an exclusive and easily identified submetacentric pair in the samples with $2 n=52 / 51$ chromosomes (groups $\mathrm{C}$ and D). Thus, it is likely that a centric fusion between two nonhomologous acrocentric chromosomes, involving one of the 

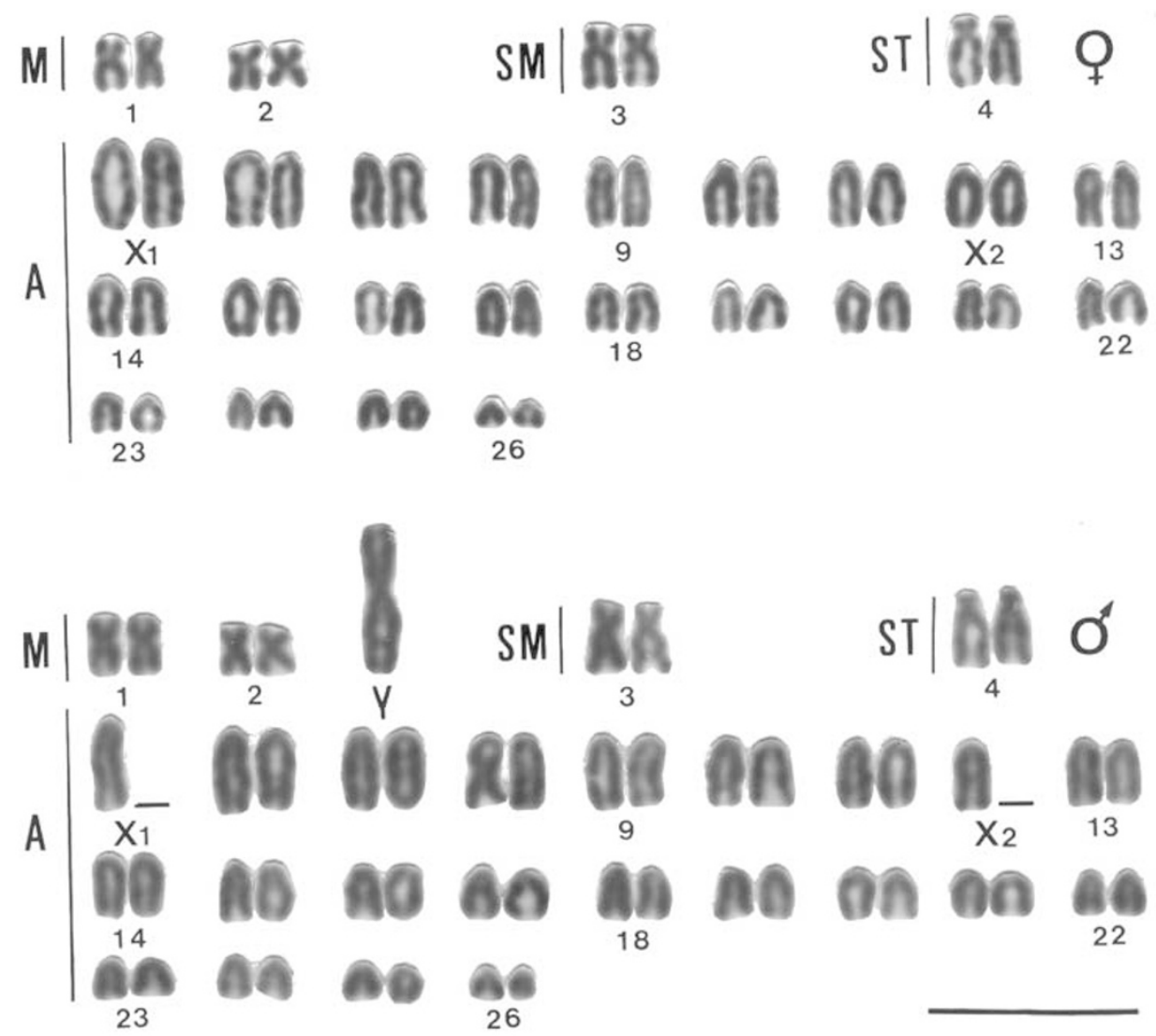

Figure 5 Karyotypes of E. erythrinus from Natal (group D), showing $2 n=52$ chromosomes in females and $2 n=51$ chromosomes in males, with an $X_{1} X_{1} X_{2} X_{2} / X_{1} X_{2} Y$ sex chromosome system. Bar $=5 \mu \mathrm{m}$.

smallest of the karyotype - and nowadays fixed in a homozygous condition in the $2 n=52 / 51$ samples - is related to these numerical and structural modifications. Furthermore, additional pericentric inversions must have completed the karyotypic differentiation, decreasing the number of acrocentric chromosomes and increasing the number of subtelocentric ones in group $\mathrm{C}$ (Figure 4; Table 1), or decreasing the number of metacentric chromosomes and increasing the number of acrocentric ones in group D (Figure 5; Table 1).

Nevertheless, the most remarkable aspect in the E. erythrinus karyotypic differentiation is the presence of a multiple sex chromosomes system of the $X_{1} X_{1} X_{2} X_{2} /$ $\mathrm{X}_{1} \mathrm{X}_{2} \mathrm{Y}$ type in the samples of groups B-D. A comparative analysis of male and female karyotypes clearly suggests that a centric fusion may have created the largest metacentric $\mathrm{Y}$ chromosome. Consequently, the resulting acrocentric chromosomes without homologues in males correspond to the $X_{1}$ and $X_{2}$ chromosomes, which are tentatively identified as the 5th and 12th pairs in the karyotypes, respectively (Figures 3 and 5). Complementary analyses will be necessary for a better identification of these chromosomes. Although the male karyotype from Manaus (group C) is not available at this moment, the preliminary identification of the $X_{1} X_{2} Y$ sex system for this sample (Falcão, personal communication), agrees with those present in the B and D samples. The other three samples of the group A did not display chromosomal differentiation between sexes.
Three different sex chromosome systems have already been identified in the family Erythrinidae, one being the $\mathrm{XX} / \mathrm{XY}$ type (Born and Bertollo, 2000) and the remaining corresponding to multiple systems of the $X_{1} X_{1} X_{2} X_{2} /$ $\mathrm{X}_{1} \mathrm{X}_{2} \mathrm{Y}$ and $\mathrm{XX} / \mathrm{XY}_{1} \mathrm{Y}_{2}$ types (Bertollo et al, 1997; Bertollo and Mestriner, 1998). All these systems were found in Hoplias malabaricus, which also shows cytotypes with no sex chromosome differentiation, thus suggesting the existence of a probable species complex (Bertollo et al, 2000). None of the Hoplerythrinus unitaeniatus samples studied so far have displayed sex chromosome heteromorphism (Giuliano-Caetano et al, 2001; Bezerra, 2002). The present results show that some samples of E. erythrinus also have an $\mathrm{X}_{1} \mathrm{X}_{1} \mathrm{X}_{2} \mathrm{X}_{2} / \mathrm{X}_{1} \mathrm{X}_{2} \mathrm{Y}$ sex chromosome system, while some others do not present any karyotypic differentiation between males and females. In addition, the occurrence of the same $\mathrm{X}_{1} \mathrm{X}_{2} \mathrm{Y}$ chromosomal system in samples with different diploid numbers $(2 n=54 / 53$ and 52/51) indicates that such differentiation preceded the numerical divergence among these groups. Figure 6 summarizes the available chromosomal data, with the indication of a probable evolutionary karyotypic pathway in E. erythrinus.

Another relevant feature, not yet detected in the Erythrinidae, is the occurrence of additional microchromosomes in the Birigui (group A) and Guaíra (group B) samples (Figures 2a and 3). In the best chromosome spreads, they display a morphology that resembles that of 'double minute chromosomes'. Apparently, they are 


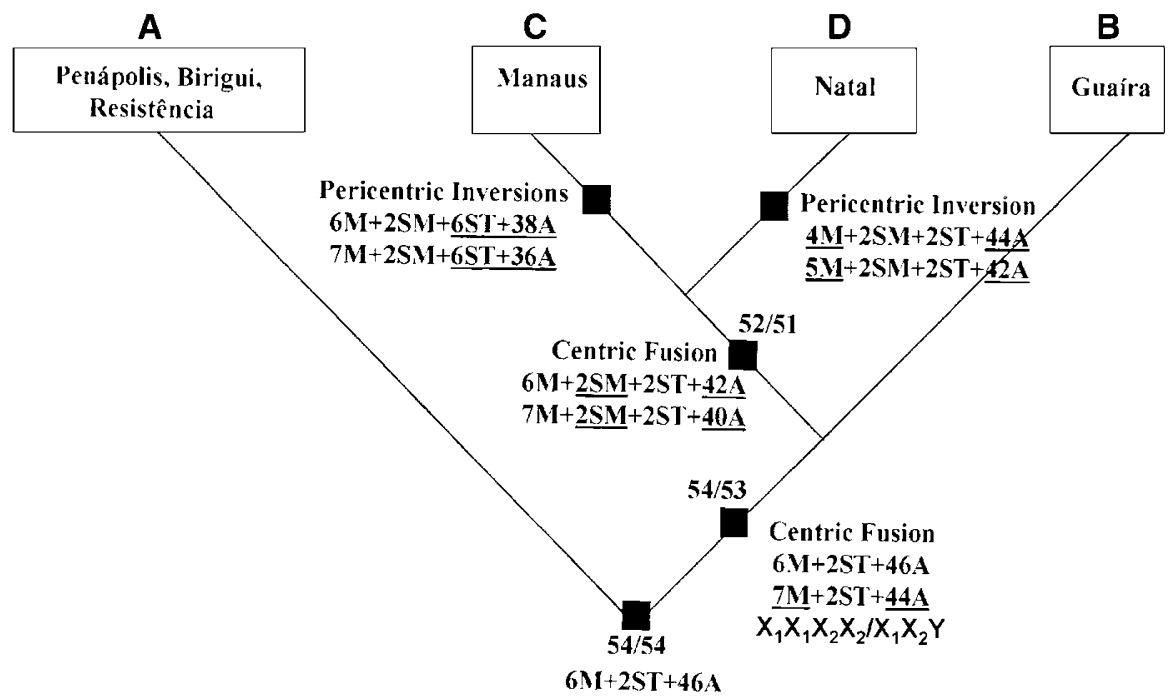

Figure 6 Evolutionary pathway proposed for the groups A-D of E. erythrinus, on the basis of their karyotypic features. The main chromosomal modifications from a basal karyotype are underlined.

mitotically unstable chromosomes, as manifested by their intraindividual between-cell variation in number in the Birigui sample. Indeed, a mitotic instability can generate cells with different chromosomal numbers. According to the proposed karyotypic evolution (Figure 6), these additional microchromosomes could have already been present in the $2 n=54 / 54$ ancestral karyotype, and were lost in the putative ancestor of groups $\mathrm{C}$ and $\mathrm{D}$.

The karyotypic diversity that had been found in the Erythrinidae fish, especially in Hoplias malabaricus and Hoplerythrinus unitaeniatus, is now also confirmed in E. erythrinus, allowing a precise characterization of many local samples. Indeed, the distinct chromosomal features of E. erythrinus (Figure 6) were found among isolated samples in nature, where the chromosomal rearrangements are already fixed, suggesting the existence of several unnamed new species in this fish group. Thus, this nominal species appears to correspond to a species complex. The further analysis of some samples with different banding techniques will be helpful to a better understanding of the origin of the sex chromosomes in Erythrinus.

\section{Acknowledgements}

This study was supported by CNPq (Conselho Nacional de Desenvolvimento Científico e Tecnológico).

\section{References}

Bertollo LAC, Born GG, Dergam JA, Fenocchio AS, MoreiraFilho $O$ (2000). A biodiversity approach in the neotropical Erythrinidae fish, Hoplias malabaricus. Karyotypic survey, geographic distribution of cytotypes and cytotaxonomic considerations. Chromosome Res 8: 603-613.

Bertollo LAC, Fontes MS, Fenocchio AS, Cano J (1997). The $\mathrm{X}_{1} \mathrm{X}_{2} \mathrm{Y}$ sex chromosome system in the fish Hoplias malabaricus. I. G-, C- and chromosome replication banding. Chromosome Res 5: 493-499.
Bertollo LAC, Mestriner CA (1998). The $\mathrm{X}_{1} \mathrm{X}_{2} \mathrm{Y}$ sex chromosome system in the fish Hoplias malabaricus. II. Meiotic analyses. Chromosome Res 6: 141-147.

Bertollo LAC, Takahashi CS, Moreira-Filho O (1978). Cytotaxonomic considerations on Hoplias lacerdae (Pisces, Erythrinidae). Brazil J Genet 1: 103-120.

Bezerra DD (2002). Estudos Citogenéticos Populacionais em Hoplerythrinus unitaeniatus (Pisces, Erythrinidae). Análise da Biodiversidade. MSc Thesis Universidade Federal de São Carlos.

Born GG, Bertollo LAC (2000). An XX/XY sex chromosome system in a fish species, Hoplias malabaricus, with a polymorphic NOR-bearing chromosome. Chromosome Res 8: 111-118.

Foresti F, Oliveira C, Almeida-Toledo LF (1993). A method for chromosome preparations from large fish specimens using in vitro short-term treatment with colchicine. Experientia 49: 810-813.

Giuliano-Caetano L, Jorge LC, Moreira-Filho O, Bertollo LAC (2001). Comparative cytogenetic studies on Hoplerythrinus unitaeniatus populations (Pisces, Erythrinidae). Cytologia 66: 39-43.

Kosswig G (1973). The role of fish in research on genetics and evolution. In: Schroder JH (ed) Genetics and Mutagenesis of Fish. Springer-Verlag: Berlin, pp 3-16.

Lee MR, Elder FFB (1980). Yeast stimulation of bone marrow mitosis for cytogenetic investigations. Cytogenet Cell Genet $\mathbf{2 6}$ $36-40$.

Levan A, Fredga K, Sandberg AA (1964). Nomenclature for centromeric position on chromosomes. Hereditas 52: 201-220.

Morelli S (1998). Citogenética Evolutiva em Espécies do Gênero Hoplias, grupo lacerdae. Macroestrutura Cariotípica, Heterocromatina e Regiões Organizadoras de Nucléolo. PhD Thesis Universidade Federal de São Carlos.

Ohno S (1974). Genome size changes without chromosomal changes and the enigma of 48 acrocentrics. In: John B (ed) Animal Cytogenetics. Gebrüder Borntraeger: Berlin, Vol 4, pp 32-46.

Oliveira C, Almeida-Toledo LF, Foresti F, Bristski HA, ToledoFilho SA (1988). Chromosome formulae of neotropical freshwater fishes. Brazil J Genet 11: 577-624.

Oyakawa OT (2003). Family Erythrinidae. In: Reis RE, Kullander SO, Ferraris Jr CJ (eds) Check List of the Freshwater Fishes of South America. Edipucrs: Porto Alegre, pp 238-240. 